\title{
Calibration of in situ chlorophyll fluorometers for organic matter
}

\author{
Jonna Kuha $\cdot$ Marko Järvinen • Pauliina Salmi $\mathbb{D} \cdot$ Juha Karjalainen
}

Received: 1 February 2019/Revised: 16 September 2019/Accepted: 28 September 2019/Published online: 5 November 2019 (C) The Author(s) 2019

\begin{abstract}
Organic matter (OM) other than living phytoplankton is known to affect fluorometric in situ assessments of chlorophyll in lakes. For this reason, calibrating fluorometric measurements for OM error is important. In this study, chlorophyll (Chl) fluorescence was measured in situ in multiple Finnish lakes using two sondes equipped with $\mathrm{Chl}$ fluorometers (ex.470/em.650-700 nm). OM absorbance $\left(\mathrm{A}_{420}\right)$ was measured from water samples, and one of the two sondes was also equipped with in situ fluorometer for $\mathrm{OM}$ (ex.350/em.430 nm). The sonde with Chl and OM fluorometers was also deployed continuously on an automated water quality monitoring station on Lake Konnevesi. For data from multiple lakes, inclusion of water colour estimates into the calibration model improved the predictability of Chl assessments markedly. When OM absorbance or in situ OM fluorescence was used in the calibration model,
\end{abstract}

Guest editors: Tom Jilbert, Raoul-Marie Couture,

Brian J. Huser \& Kalevi Salonen / Restoration of eutrophic lakes: current practices and future challenges

J. Kuha $(\bowtie) \cdot$ P. Salmi · J. Karjalainen

Department of Biological and Environmental Science, University of Jyväskylä, PO Box 35, 40014 Jyväskylä, Finland

e-mail: jonna.kuha@jyu.fi

\section{Järvinen}

Freshwater Centre/Water Information System Unit, Finnish Environment Institute (SYKE), Latokartanonkaari 11, 00790 Helsinki, Finland predictability between the in situ $\mathrm{Chl}$ and laboratory Chl a assessments was also enhanced. However, correction was not superior to the one done with the water colour estimate. Our results demonstrated that correction with water colour assessments or in situ measurements of OM fluorescence offers practical means to overcome the variation due to $\mathrm{OM}$ when assessing Chl in humic lakes in situ.

Keywords Automated monitoring - Chlorophyll a · Fluorescence · Organic matter - Optical sensors · Water colour

\section{Introduction}

Phytoplankton biomass is widely used as an indicator of eutrophication in the status assessment of surface waters. Chlorophyll $a$ concentration is used as a proxy for phytoplankton biomass, traditionally quantified in laboratory from water samples by ethanol extraction followed by spectrophotometric measurement at wavelengths 665 and $750 \mathrm{~nm}$ (Lorenzen, 1967); ISO 10260, 1992). The shortcomings of this protocol are also well known: it requires large sample volumes, sample transportation, storage and handling. Therefore, spatial and temporal coverage and representativeness of traditional measurements are generally limited. During the last two decades, field 
spectrofluorometers to measure chlorophyll in situ have become increasingly common worldwide (Meinson et al., 2015). In the text, we use "Chl $a$ " to refer to chlorophyll $a$ concentration measured in laboratory, in contrast to "Chl" that refers to in situ fluorescence of chlorophyll.

Due to the ease of measuring, Chl fluorometers are frequently used to study phytoplankton distribution, activity and population dynamics in situ (Proctor \& Roesler, 2010; Zeng \& Li, 2015). Fluorometric quantification of $\mathrm{Chl}$ is generally cost-effective and allows frequent observations during sudden phenomena such as mixing events or short-lived algal blooms (Jennings et al., 2012; Klug et al., 2012). On the other hand, interpretation of in situ Chl fluorometer data is not straightforward. Values yielded by the fluorometers are arbitrary and need to be calibrated to, for example, traditional $\mathrm{Chl} a$ concentrations in order to interpret the measurements, and calibration is affected by several sources of variation. In addition to phytoplankton biomass, the intensity of Chl fluorescence is dependent on the pigment composition and physiological reactions of phytoplankton (Williams \& Bridges, 1964; Seppälä \& Balode, 1998; Richardson et al., 2010). Physical and chemical conditions in the water also affect the in situ Chl fluorescence. Such variables include changes in the underwater light and temperature conditions, back scattering and absorption of light by other particles than phytoplankton (Strickland, 1968; Carder et al., 1991; Serra et al., 2009; Downing et al., 2012; Ostrowska, 2012). Most prominently, Chl fluorescence signal is affected by fluorescence of organic matter (OM) related to something else than living phytoplankton (Proctor \& Roesler, 2010; Twiss, 2011).

Practices on how to control the sources of error due to $\mathrm{OM}$ are under a vigorous scientific discussion. $\mathrm{OM}$ is a broad term, including DOM (dissolved organic matter) and POM (particulate organic matter). In literature, OM correction has been conducted by using concepts of soluble fluorescence (Carlson \& Shapiro, 1981), yellow substances (Twiss, 2011), fluorescent or chromophoric dissolved organic matter (CDOM; Proctor \& Roesler, 2010) or humic substances (Carlson \& Shapiro, 1981). In this study, we use the general term OM to describe organic material other than phytoplankton in the lake water, because we did not fractionate or characterize the different OM components. Previous studies have shown that the OM signal is generally linked to allochthonous dissolved humic substances in boreal lakes (Carlson \& Shapiro, 1981; Twiss, 2011). In the marine environment, phytoplankton degradation products may comprise a larger part of total OM (Xing et al., 2017).

The variety of proposed measures to control the OM signal is broad, indicating its importance in $\mathrm{Chl}$ fluorescence problematics. Carlson \& Shapiro (1981) filtered a sample water to subtract OM background from Chl fluorescence in North American lakes and Leppä et al. (1995) followed the same protocol in Finnish lakes. Twiss (2011) and Proctor \& Roesler (2010) used multiple waveband sensors to measure fluorescent $\mathrm{OM}$ in lakes and to establish a calibration model between Chl and OM, whereas Xing et al. (2017) used a single waveband sensor for fluorescent $\mathrm{OM}$ to correct in situ Chl fluorescence values in deep vertical profiles from marine environment. In situ Chl fluorometers are becoming increasingly common in the monitoring of inland waters, but international standards for field operation are still under development (e.g. Lavigne et al., 2012; Cremella et al., 2018). In the near future, increase in water colour may become more important due to browning of boreal lakes (Monteith et al., 2007; Evans et al., 2012; Kritzberg \& Ekström, 2012). Corrections of Chl for OM fluorescence would thus become increasingly relevant in monitoring.

In boreal lakes, the connection between dissolved $\mathrm{OM}$ and water colour is typically strong and rather uniform due to the presence of humic substances (Carlson \& Shapiro, 1981; Hessen \& Tranvik, 1998; Keskitalo \& Eloranta, 1999). Results by Leppä et al. (1995) indicated good correlation between water colour and background fluorescence in fourteen lakes in Eastern Finland. For this reason, and the simplicity of water colour measurement, the main aim of this study was to scrutinize water colour as a proxy for OM in correction in humic lakes. In this study, we tested an in situ OM fluorescence sensor to correct $\mathrm{Chl}$ results. Major fluorescence peaks for humic substances in water consist of excitation between 330 and $390 \mathrm{~nm}$ and emission between 420 and $500 \mathrm{~nm}$ wavelengths (Matilainen et al., 2011), and the OM sensor deployed in this study covered the same wavelength range. We hypothesized that correcting fluorometric $\mathrm{Chl}$ data with (1) average or median water colour, (2) water colour at the measurement depth assessed via absorbance $\left(\mathrm{A}_{420}\right)$, or (3) in situ fluorometric 
measurements of OM improves, and equally well, the predictability between fluorometric $\mathrm{Chl}$ and traditional laboratory Chl $a$ assessment. We aimed also to obtain information of the seasonal OM variation within one lake and to determine whether continuous monitoring of $\mathrm{Chl}$ could benefit from the $\mathrm{OM}$ calibration.

\section{Materials and methods}

Study lakes

This study was conducted on lakes located in Central and Southern Finland (N-Europe) varying in size, nutrient concentration and water colour (Table 1). To understand lake-specific effects of different calibration models, Lakes Konnevesi and Jyväsjärvi in Central Finland and Lakes Vesijärvi and Vanajavesi in Southern Finland were scrutinized separately. Of the lakes, Jyväsjärvi and Vanajavesi represent small and large humic lakes, respectively. Based on their typical Chl $a$ and total phosphorus concentrations (Table 1), these lakes are oligo-mesotrophic. Lakes Konnevesi and Vesijärvi represent large clearwater lakes, the latter being oligotrophic and the former a more eutrophic lake.

In situ Chl measurements and Chl a laboratory analysis

In situ measurements on the selected lakes were done with two separate YSI6600 multiparameter sondes (type V2-4; YSI Inc., Yellow Springs, OH, USA; hereafter Sondes 1 and 2) that were equipped with $\mathrm{Chl}$ fluorometers (ex.470/em.650-700 nm) without temperature correction. Sonde 1 was used to measure $\mathrm{Chl}$ fluorescence on six of the study lakes including both humic and clearwater lakes (Table 1). Samples for the laboratory analysis of $\mathrm{Chl} a$ were taken at the depth of $1 \mathrm{~m}$ and several other depths from the lakes measured with Sonde 1 (see the link in Data availability for values). Samples were taken with a 4.41 Limnos-tube sampler and stored in cool $\left(6^{\circ} \mathrm{C}\right)$ and dark until the analysis within $24 \mathrm{~h}$ after the collection. Chl $a$ (SFSISO 10260:1992) was measured in the laboratory after filtration of $0.5-1.01$ of sample water through GF/C filters. Chl $a$ was measured using the cold ethanol extraction method and water colour spectrophotometrically. Wavelengths 665 and $750 \mathrm{~nm}$ were measured

Table 1 Locations and basic limnological characteristics of the study sites

\begin{tabular}{|c|c|c|c|c|c|c|c|c|c|}
\hline \multirow[t]{2}{*}{ Lake } & \multicolumn{2}{|c|}{ Coordinates $(\sim$ WGS84 $)$} & \multirow{2}{*}{$\begin{array}{l}\text { Area } \\
\text { (ha) }\end{array}$} & \multicolumn{2}{|c|}{ Depth (m) } & \multirow{2}{*}{$\begin{array}{l}\text { Tot-P, } \\
\left(\mu \mathrm{g} \mathrm{l}^{-1}\right)\end{array}$} & \multirow{2}{*}{$\begin{array}{l}\text { Chl } a, \\
\left(\mu \mathrm{g} \mathrm{l}^{-1}\right)\end{array}$} & \multirow{2}{*}{ 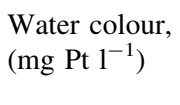 } & \multirow[t]{2}{*}{ Sonde } \\
\hline & $\overline{\text { Lat }}$ & Lon & & $\overline{\operatorname{Max}}$ & Mean & & & & \\
\hline Alvajärvi & $62^{\circ} 18^{\prime} 50.004^{\prime \prime}$ & $25^{\circ} 43^{\prime} 11.655^{\prime \prime}$ & 210 & 16.5 & 3.8 & 29 & 16.5 & 80 & 1 \\
\hline Jyväsjärvi & $62^{\circ} 14^{\prime} 11.671^{\prime \prime}$ & $25^{\circ} 46^{\prime} 2.868^{\prime \prime}$ & 314 & 25.0 & 7.0 & 25 & 10.8 & 70 & 1 \\
\hline Konnevesi & $62^{\circ} 37^{\prime} 57.366^{\prime \prime}$ & $26^{\circ} 36^{\prime} 16.504^{\prime \prime}$ & 19,028 & 57.1 & 10.6 & 6 & 4.2 & 25 & 1 \\
\hline Ruokojärvi & $62^{\circ} 15^{\prime} 32.902^{\prime \prime}$ & $27^{\circ} 18^{\prime} 41.28^{\prime \prime}$ & 464 & 8.2 & 1.3 & 30 & 10.6 & 110 & 1 \\
\hline Vanajavesi & $61^{\circ} 9^{\prime} 19.713^{\prime \prime}$ & $24^{\circ} 13^{\prime} 44.982^{\prime \prime}$ & 10,261 & 23.9 & 7.7 & 24 & 16.0 & 50 & 1 \\
\hline Vesijärvi & $61^{\circ} 3^{\prime} 1.662^{\prime \prime}$ & $25^{\circ} 35^{\prime} 4.926^{\prime \prime}$ & 6,471 & 40.0 & 6.1 & 27 & 9.6 & 10 & 1 \\
\hline Alasenjärvi & $61^{\circ} 0^{\prime} 46.564^{\prime \prime}$ & $25^{\circ} 44^{\prime} 35.29^{\prime \prime}$ & 275 & 15.2 & 6.1 & 14 & 4.5 & 10 & 2 \\
\hline Alinen Rautjärvi & $61^{\circ} 11^{\prime} 43.098^{\prime \prime}$ & $25^{\circ} 6^{\prime} 1.241^{\prime \prime}$ & 50 & 12.0 & No data & 23 & 23.0 & 100 & 2 \\
\hline Arkiomaanjärvi & $61^{\circ} 3^{\prime} 14.659^{\prime \prime}$ & $25^{\circ} 44^{\prime} 26.692^{\prime \prime}$ & 208 & 20.2 & 5.1 & 17 & 5.3 & 25 & 2 \\
\hline Joutjärvi & $60^{\circ} 58^{\prime} 36.406^{\prime \prime}$ & $25^{\circ} 42^{\prime} 6.567^{\prime \prime}$ & 40 & 5.0 & 3.3 & 25 & 24.0 & 20 & 2 \\
\hline Merrasjärvi & $61^{\circ} 1^{\prime} 3.695^{\prime \prime}$ & $25^{\circ} 41^{\prime} 4.868^{\prime \prime}$ & 24 & 2.6 & 1.5 & 31 & 19.3 & 50 & 2 \\
\hline Pääjärvi & $61^{\circ} 3^{\prime} 48.76^{\prime \prime}$ & $25^{\circ} 7^{\prime} 56.998^{\prime \prime}$ & 1,352 & 85.0 & 14.8 & 12 & 5.5 & 70 & 2 \\
\hline Ruuhijärvi & $61^{\circ} 1^{\prime} 38.011^{\prime \prime}$ & $26^{\circ} 0^{\prime} 28.054^{\prime \prime}$ & 573 & 18.7 & 5.6 & 18 & 10.8 & 30 & 2 \\
\hline Työtjärvi & $60^{\circ} 59^{\prime} 44.515^{\prime \prime}$ & $25^{\circ} 28^{\prime} 2.635^{\prime \prime}$ & 56 & 7.0 & $<1.5$ & 23 & No data & 50 & 2 \\
\hline
\end{tabular}

Limnological data from the database of Finnish Environmental Institute (SYKE) or Dolman et al. (2015)

Sonde refers to either of the two multiparameter sondes (Sonde 1 and Sonde 2) that was deployed on the lake

Tot-P total phosphorus concentration, Chl $a$ chlorophyll $a$ concentration 
with the Shimadzu UV-1800 spectrophotometer (Shimadzu Co., Kyoto, Japan) in 5-cm quartz cuvettes.

Sonde 2 was used to measure $\mathrm{Chl}$ fluorescence in eight lakes, also including humic and clearwater lakes (Table 1). Vertical profiles were recorded, as for Sonde 1, and integrated (0-2 m) samples for Chl $a$ collected with a Limnos sampler. Chl $a$ samples were filtered using Whatman GF/F filters and stored in a freezer $\left(-20^{\circ} \mathrm{C}\right)$ until measurement within 1-3 weeks after sampling using a hot ethanol extraction method and spectrophotometer (SFS-ISO 10260, 1992; Dolman et al., 2015). The methods for Chl $a$ extraction were different for the two datasets, because the extractions were carried out in two different institutes (Lammi Biological Station of University of Helsinki and University of Jyväskylä). However, both methods are general and well-established procedures in laboratory analysis of $\mathrm{Chl} a$.

Water colour of the study lakes (colour $r_{\text {typical }}$ )

In this study, we first tested the epilimnetic water colour of the study lakes as a parameter (hereafter colour $_{\text {typical }}$ ) to correct Chl measurements. For most of the study lakes, these colour values, also used for lake typology classification, were available from the database of Finnish Environment Institute (SYKE, https://wwwp2.ymparisto.fi/scripts/kirjaudu.asp, requires free registration and use of website translator). Water colour was analysed either with a Hellige/AVM Neocomparator or spectrophotometrically (wavelength $410 \mathrm{~nm}$ ) according to SFS-EN-ISO 7887:2011. The water colour of the methods are highly comparable. For four of the study lakes, colour $r_{\text {typical value was }}$ taken from Dolman et al. (2015), and were determined using spectrophotometric analysis from $0.45 \mu \mathrm{m}$ prefiltered samples (SFS-EN-ISO 7887, 2011, $410 \mathrm{~nm}$ ).

On site water colour measurements ( colour $_{\text {Lab }}$ )

From the lakes measured with Sonde 1, samples for the laboratory analysis of water colour $\left(\right.$ colour $_{\mathrm{Lab}}$ ) were taken at the same depths as samples for laboratory analysis of Chl $a$ (see the link in Data availability for values). Samples were taken as subsamples from the 4.4-1 Limnos-tube sampler and stored in cool and dark conditions until the analysis within $24 \mathrm{~h}$ after the collection. Water colour was measured in the laboratory after filtration of $0.5-1.01$ of sample water through GF/C filters. Absorbance at $420 \mathrm{~nm}$ wavelength was measured with the Shimadzu UV-1800 spectrophotometer using 1-cm quartz cuvettes and converted to $\mathrm{mg} \mathrm{Pt}^{-1}$ (SFS-EN-ISO 7887, 2011).

In situ fluorescence of organic matter

Sonde 1 was equipped with Cyclops- 7 organic matter (OM) fluorometer (ex.350/em.430 nm; Turner Designs Inc., Sunnyvale, CA, USA). The OM fluorometer was calibrated for water temperature as in Watras et al. (2011), for which the temperature coefficient $(\rho)$ of -0.009 was used to transform data to a reference temperature of $20^{\circ} \mathrm{C}\left(\mathrm{RFU}_{20}\right)$.

Continuous water quality monitoring on Lake Konnevesi

To test the performance of different calibration methods and to study seasonal variation in $\mathrm{Chl}$ and $\mathrm{OM}$, Sonde 1 was continuously also deployed in Lake Konnevesi during the open water season in 2013 (June-October). One profile in every three hours at $0.5-\mathrm{m}$ step was recorded from the 42-m-deep water column. Daily averages of $\mathrm{Chl}$ and OM from 1.5 to $2.0 \mathrm{~m}$ depth were taken into analysis. Surface $(0-\mathrm{m})$ Chl $a$ data from 2013 were collected by the regional environmental agency KES-ELY during the open water period (June-October, $n=5$, Database of Finnish Environment Institute) and supplemented by our Chl $a$ samplings $(n=4)$ from $1 \mathrm{~m}$ and $2 \mathrm{~m}$ depths with the Limnos sampler. Regression models (Table 2a, b) developed for the multiple lakes dataset were tested to calibrate the continuous $\mathrm{Chl}$ data.

\section{Comparison of the calibration methods}

We compared Chl fluorometer data and corresponding $\mathrm{Chl} a$ results from laboratory analyses and established calibration equations for the Chl fluorometer by fitting a linear regression model. Then we added water colour (colour $_{\text {Typical }}$ ) into the calibration equation. For Sonde 1, we also used colour ${ }_{\text {Lab }}$ taken at the time of profile measurements and included of in situ OM fluorometer data into the calibration models. Surface (average of 1-2 m) Chl and OM fluorometer results from Lake Konnevesi (Central Finland) were corrected with each of the established calibration equations, excluding 
Table 2 Univariate and multivariate linear regression models for the calibration of the Sonde 1 (a) and Sonde 2 (b) fluorometers using the laboratory measured chlorophyll $a$

\begin{tabular}{llll}
\hline a. Model equation for Sonde 1 & $n$ & $\mathrm{R}^{2}$ & $P$ \\
\hline (1) Chl $a=1.717(\mathrm{Chl})-1.944$ & 71 & 0.537 & $<0.014$ \\
(2) Chl $a=3.024(\mathrm{Chl})-0.162\left(\right.$ colour $\left._{\text {typical }}\right)-1.877$ & 71 & 0.816 & $<0.001$ \\
(3) Chl $a=2.843(\mathrm{Chl})-0.133\left(\right.$ colour $\left._{\text {Lab }}\right)-1.067$ & 71 & 0.879 & $<0.001$ \\
(4) Chl $a=2.288(\mathrm{Chl})-5.109(\mathrm{OM})+3.613$ & 71 & $R^{2}$ & $<0.001$ \\
\hline b. Model equation for Sonde 2 & $n$ & 0.537 & $<0.001$ \\
\hline (1) Chl $a=0.811(\mathrm{Chl})-4.902$ & 71 & 0.914 & $<0.001$ \\
(2) Chl $a=1.076(\mathrm{Chl})-0.165\left(\right.$ colour $\left._{\text {typical }}\right)-2.938$ & 71 &
\end{tabular}

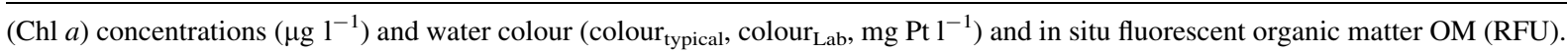
$n$ number of observations (samplings on lakes) used to construct the models

colour $_{\text {Lab }}$, to illustrate the feasibility of the calibration for automated water quality monitoring.

Calculations of modelling efficiency $\left(\mathrm{ME}=1-\sum\left(y_{\mathrm{o}}-y_{\mathrm{p}}\right)^{2} / \sum\left(y_{\mathrm{o}}-y_{\mathrm{m}}\right)^{2}\right)$, where $y_{\mathrm{o}}$ represents observed values, $y_{p}$ predicted values, and $y_{\mathrm{m}}$ the mean of observed values, and mean absolute percentage error $\left(\operatorname{MAE}(\%)=100\left[\sum\left(\left|y_{\mathrm{o}}-y_{\mathrm{p}}\right| / y_{\mathrm{o}} \mid\right)\right] /\right.$ $n$,), where $n$ is the number of pairs, were conducted according to Mayer \& Butler (1993) using Microsoft Excel (2010, Microsoft Co., Redmond, WA, USA). Linear regressions and statistical tests were conducted

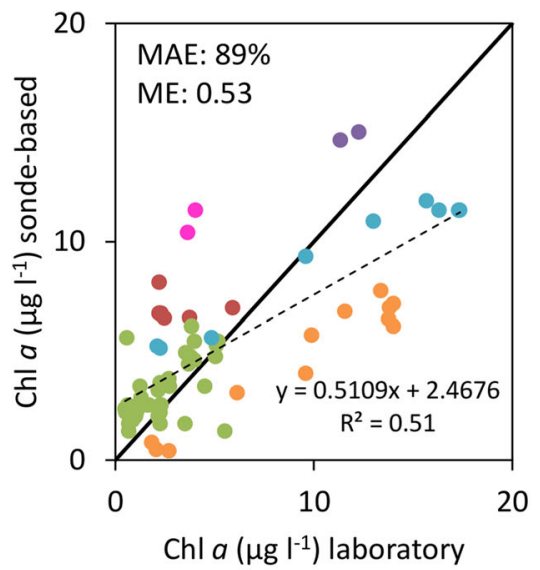

\section{Alvajärvi Jyväsjärvi Konnevesi Ruokojärvi Vanajavesi Vesijärvi}

Fig. 1 Linear regression (broken line) between the observed Chl $a$ concentrations and estimated Chl $a$ concentrations based on the calibration with measured $\mathrm{Chl} a$ in the study lakes (model with SPSS software (version 22.0, IBM Co., Chicago, IL, USA). Results with $P<0.05$ were reported significant.

\section{Results}

In the lakes measured with Sonde 1 (see Table 1), manually sampled $\mathrm{Chl} a$ concentration varied between 0.5 and $17.4 \mu \mathrm{g}^{-1}$, and in the lakes measured with Sonde 2 between 3.6 and $43.7 \mu \mathrm{g}^{-1}$ (Fig. 1). After

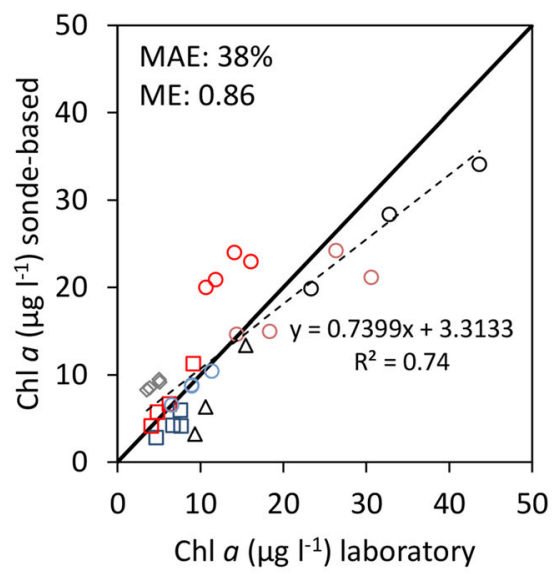

$\begin{array}{ll}\square \text { Alasenjärvi } & \bigcirc \text { Alinen Rautjärvi } \\ \square \text { Arkiomaanjärvi } & \triangle \text { Joutjärvi } \\ \bigcirc \text { Merrasjärvi } & \diamond \text { Pääjärvi } \\ \bigcirc \text { Ruuhijärvi } & \bigcirc \text { Työtjärvi }\end{array}$

1; see Table 2a, b). Solid line = 1:1 line. Dots-Sonde 1 data; open markers-Sonde 2 data; MAE mean absolute percentage error (\%), $M E$ modelling efficiency (\%) 
Fig. 2 Linear regression (broken line) between the observed $\mathrm{Chl}$

$a$ concentrations and estimated Chl

$a$ concentrations based on the calibration with

measured Chl $a$ and water colour estimate

(colour $_{\text {typical }}$, Table 1).

Regression model 2 was used here (see Table 2a, b). Solid line $=1: 1$ line. DotsSonde 1 data; open markers-Sonde 2 data; $M A E$ mean absolute percentage error $(\%), M E$ modelling efficiency $(\%)$

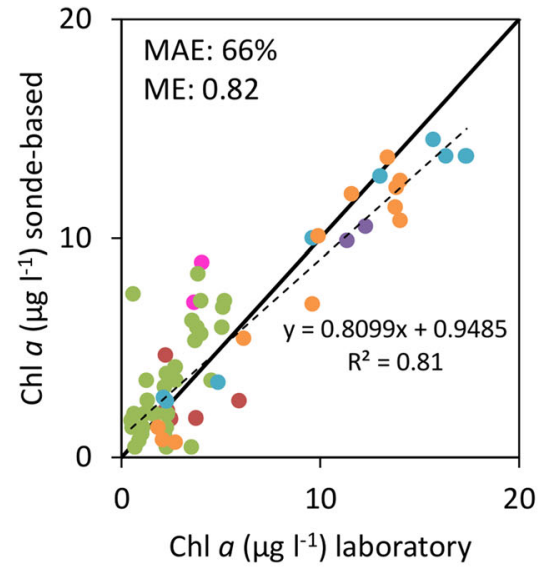

Alvajärvi Jyväsjärvi Konnevesi
Ruokojärvi Vanajavesi Vesijärvi

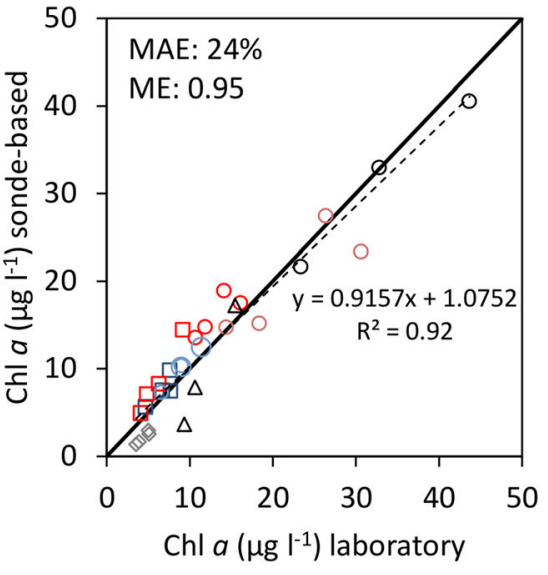

$\square$ Alasenjärvi $\bigcirc$ Alinen Rautjärv $\square$ Arkiomaanjärvi $\triangle$ Joutjärvi OMerrasjärvi $\diamond$ Pääjärvi Ruuhijärvi OTyötjärvi calibrating the fluorometer readings only with the $\mathrm{Chl}$ $a$ concentrations (model 1 , Table $2 \mathrm{a}, \mathrm{b}$ ), the regression coefficients, modelling efficiency (ME) and mean absolute percentage errors (MAE) were rather weak $\left(R^{2}=0.51\right.$ and $0.74, \mathrm{MAE}=89 \%$ and $38 \%, \mathrm{ME}=$ 0.53 and 0.86 , for Sondes 1 and 2, respectively, Fig. 1).

The respective predictabilities of model 2, including both Chl $a$ and water colour (colour typical $_{\text {) as }}$ correcting variables, were notably better for both sondes $\left(R^{2}=0.81\right.$ and 0.92, MAE $=66 \%$ and $24 \%$, $\mathrm{ME}=0.82$ and 0.95 , for Sondes 1 and 2, respectively, Fig. 2).

For Sonde 1, we also constructed models 3 and 4, including $\mathrm{Chl} a$ and colour $_{\mathrm{Lab}}$ or OM fluorescence, respectively. Model 3 yielded slightly better predictability $\left(R^{2}=0.85, \mathrm{MAE}=64 \%, \mathrm{ME}=0.86\right)$ than

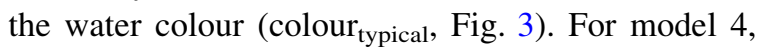
introducing $\mathrm{OM}$ fluorescence as a calibration factor was relatively effective $\left(R^{2}=0.77, \mathrm{MAE}=65 \%\right.$, $\mathrm{ME}=0.78$ ), but not superior to models 2 or 3 . Chl $a$ values yielded by different models did not differ significantly from each other (Related Samples Wilcoxon Signed Rank Test, $P>0.2$ for each combination pair of models).

The relationship between colour $_{\text {Lab }}$ and OM fluorescence $\left(\mathrm{RFU}_{20}\right)$ was logarithmic (Fig. 4): OM fluorescence first increased rapidly along colour $_{\text {Lab }}$, but in lakes with colour ${ }_{\text {Lab }}>50 \mathrm{mg} \mathrm{Pt}^{-1}$ it levelled off (Fig. 4).

Scrutinization of the performance of each model for a sub-set of lakes corroborated the general overview and demonstrated that, prior to any OM correction, the variation in the fluorometer readings calibrated only with the Chl $a$ varied notably from the Chl $a$ measurements even inside one lake (Figs. 5, 6). In humic Lakes Jyväsjärvi and Vanajavesi, the predictability between the two was moderate, but mean absolute error was high $\left(R^{2}=0.88, \mathrm{MAE}=97 \%, \mathrm{ME}=0.83\right.$, Fig. 5). In clear water lakes Konnevesi and Vesijärvi, the predictability without any OM correction was weaker but mean absolute error slightly lower $\left(R^{2}=0.56, \mathrm{MAE}=86 \%, \mathrm{ME}=0.71\right.$, Fig. 6). However, when any of the OM correction models (models 2-4 in Table 2a, b) was applied, the predictabilities increased in all four lakes. In Jyväsjärvi and Vanajavesi, the regression coefficients, mean absolute errors and the modelling efficiencies of models 2-4 varied only little $\left(R^{2}=0.93-0.97\right.$, MAE $=25-36 \% \%$, $\mathrm{ME}=0.93-0.97$, Fig. 5). Similarly, clear water lakes Konnevesi and Vesijärvi benefited from each of the calibration methods rather equally $\left(R^{2}=0.74-0.76\right.$, MAE $=74-79 \%$, ME $=0.85-0.87$, Fig. 6).

In the oligotrophic, humic Lake Konnevesi, Chl $a$ varied between 1.8 and $6.2 \mu \mathrm{g}^{-1}$ in June-October 2013, colour $_{\text {typical }}$ was $25 \mathrm{mg} \mathrm{Pt} 1^{-1}$ and OM 
Fig. 3 Linear regression (broken line) between the observed Chl

$a$ concentrations and estimated Chl

$a$ concentrations based on the calibration with measured Chl $a$ and absorbance-based water colour $\left(\mathrm{A}_{420}\right.$, left panel, model 3 in Table $2 b$ ) or in situ OM fluorescence (right panel, model 4 in Table 2b). Solid line $=1: 1$ line; $M A E$ mean absolute percentage error $(\%), M E$ modelling efficiency $(\%)$
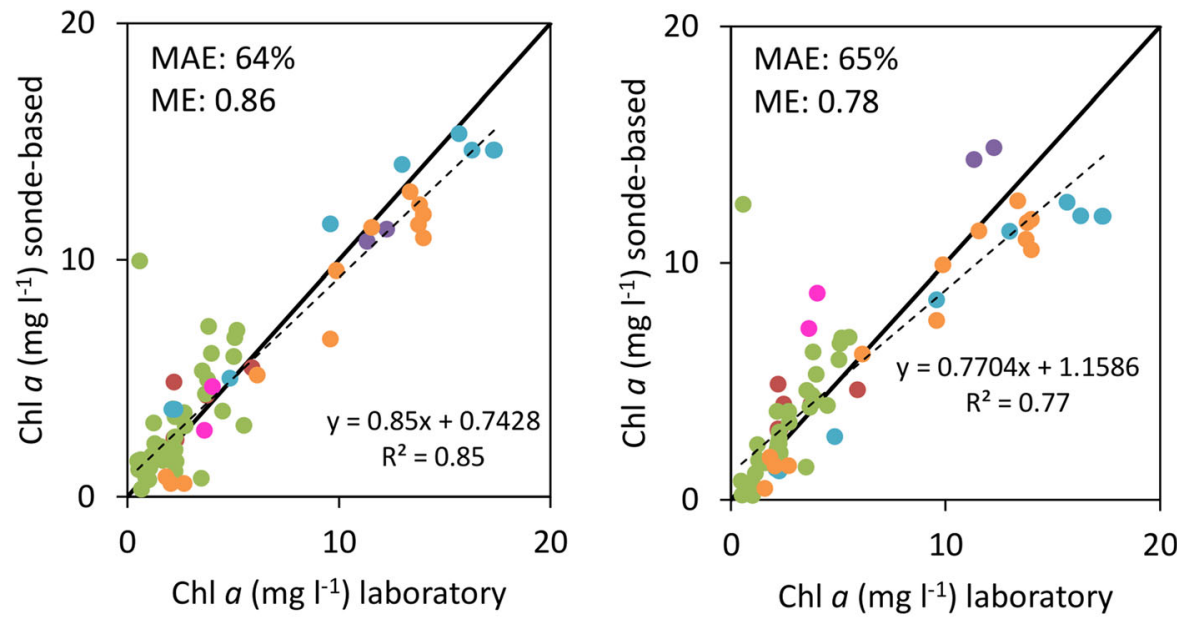

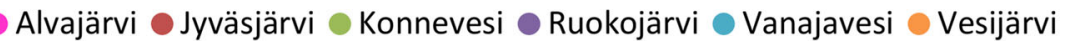

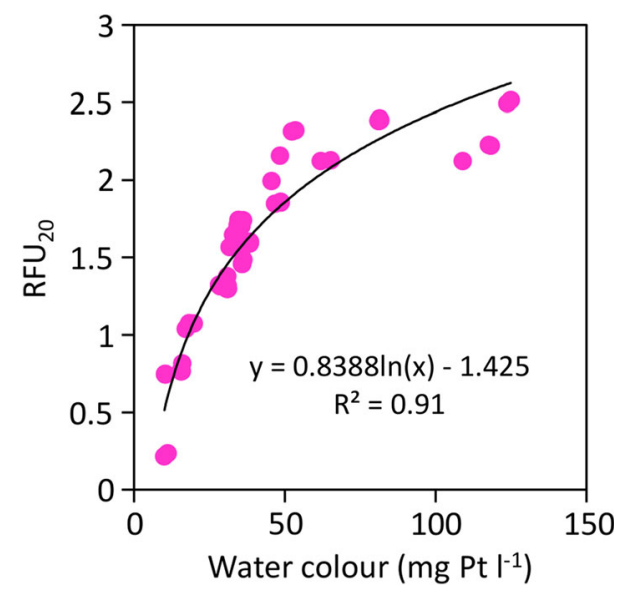

Fig. 4 Relationship between water colour and OM fluorescence $\left(\mathrm{RFU}_{20}\right)$ in the study lakes

fluorescence $\left(\mathrm{RFU}_{20}\right)$ varied between 0.95 and 58 (Fig. 7). When models 1, 2 and 4 (Table 2a) were used to correct the automated fluorometer monitoring data, only little differences between the modelled Chl $a$ results were found (Fig. 7). However, the decrease of water colour in autumn 2013, monitored with in situ $\mathrm{OM}$, produced a period with higher Chl fluorescence in September than the models using correction with only Chl $a$ or Chl $a$ and colour typical (Fig. 7).

\section{Discussion}

Our study demonstrated the use of water colour as an estimate of OM in controlling the OM fluorescence in $\mathrm{Chl}$ in situ fluorometer data. The applicability of a typical colour value of the lake in calibration was validated by comparing it with the calibrations done using simultaneously measured water colour and in situ OM fluorescence. As we expected, inclusion of any of these parameters into the calibration model improved the predictability between the in situ $\mathrm{Chl}$ fluorescence and $\mathrm{Chl} a$.

A non-linear relationship between $\mathrm{OM}$ and water colour is well documented (Watras et al., 2011; Coble et al., 2014). High concentrations of dissolved organic material in the water column affect the OM fluorescence measurements by suppressing the values at higher dissolved OM concentrations (Watras et al., 2011). We also observed this in our study lakes (Fig. 4), and it may explain why the in situ OM calibration was not a superior method over the more simplistic water colour calibration. Proctor \& Roesler (2010) outlined similarly that OM may lead to an underestimation of Chl $a$ by absorbing excitation or emission wavelengths or, on the other hand, OM may cause seemingly intensified $\mathrm{Chl}$ emission by contributing to the signal detected by Chl fluorometers. In 
Fig. 5 Performance of the calibration equations in humic Lakes Jyväsjärvi and Vanajavesi (see Table 1 for lake characteristics). Broken line represents linear regression between the observed Chl $a$ concentrations and estimated Chl $a$ concentrations based on the calibration with measured Chl $a$ (model 1, see Table $2 \mathrm{a}, \mathrm{b}$ for the models) or measured $\mathrm{Chl}$ $a$ and water colour estimate (model 2), absorbancebased water colour $\left(\mathrm{A}_{420}\right.$, model 3) or in situ OM fluorescence (model 4). Solid line = 1:1 line; $M A E$ mean absolute percentage error (\%), $M E$ modelling efficiency $(\%)$
Model 1

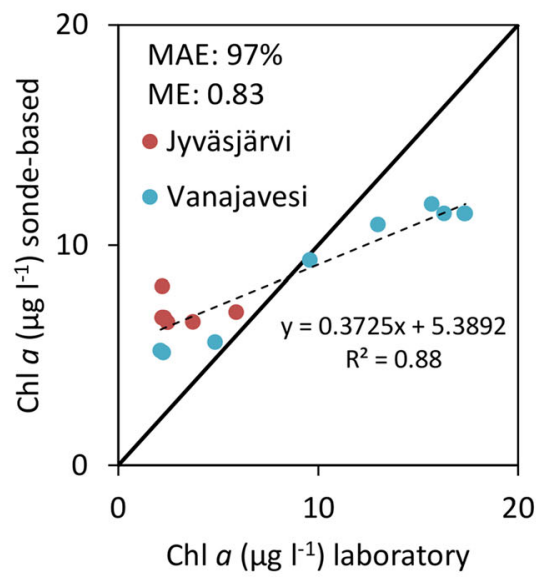

Model 3

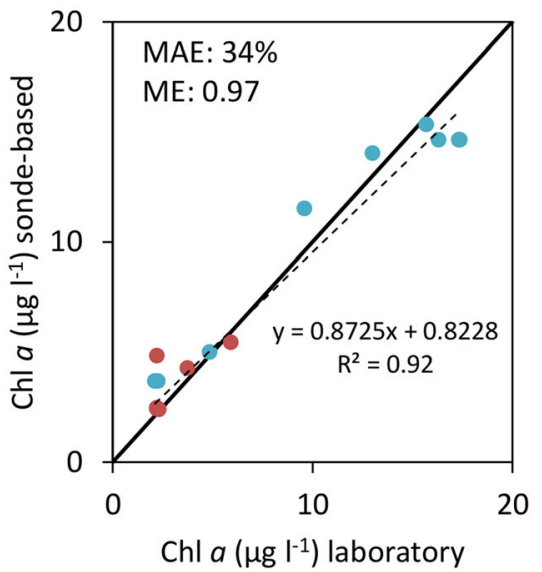

Model 2

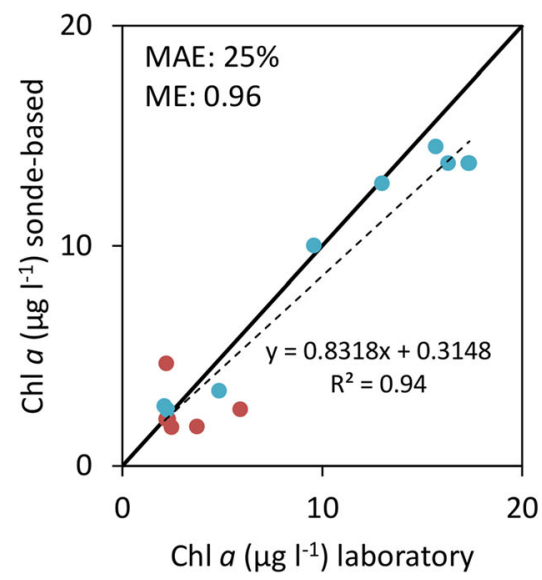

Model 4

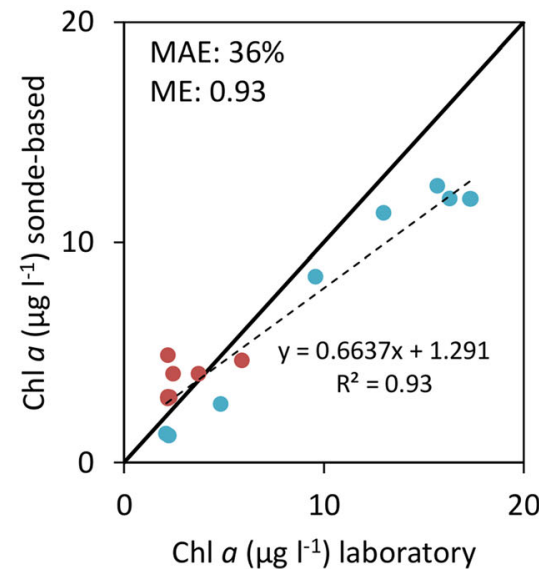

our data, the latter was typical for most of the studied lakes, except for the eutrophic and most clearwater

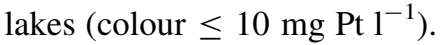

Our results agree with previous studies stating that without OM calibration, the interpretation of in situ $\mathrm{Chl}$ results is generally misleading. Proctor \& Roesler (2010) collected water samples from a lake, pond, stream and a bog in Maine (USA) with varying OM levels and measured phytoplankton and OM fluorescence with the multiple waveband fluorometers in the laboratory. They observed a linearly increasing OM signal along the OM concentration in the dilution series determined fluorometrically and spectrophotometrically. Based on the linear congruence between the OM and algae multiexciter signals, they stated that the quantity of $\mathrm{OM}$ is of central importance. Goldman et al. (2013) also showed significant overestimation of $\mathrm{Chl}$ concentration with increased $\mathrm{OM}$ concentrations in an estuary. Leppä et al. (1995) found a high background fluorescence in humic lakes of SouthEastern Finland, caused by water colour, which lead to recommendations for the Chl fluorometry calibration against the OM background.

In our study, the improvement due to calibration was not that clear in the continuously measured fluorometer data of Lake Konnevesi. However, in the end of July 2013, OM fluorescence decreased and the OM calibrated Chl fluorescence (model 4) increased leading to a better congruence with the measured $\mathrm{Chl}$ $a$, which might indicate that the continuous on-line Chl measurements could benefit from the OM calibration (Fig. 7). Likely, the significance of in situ OM correction is emphasized, compared to laboratory analyses, when $\mathrm{Chl}$ is measured with a high frequency in real time. In Lake Konnevesi, the automated system recorded a decrease of $\mathrm{OM}$ fluorescence towards the end of the summer, which is a known phenomenon in boreal lakes and associated with photochemical 
Fig. 6 Performance of the calibration equations in clear water Lakes

Konnevesi and Vesijärvi (see Table 1 for lake characteristics). Broken line represents linear regression between the observed $\mathrm{Chl}$ $a$ concentrations and estimated $\mathrm{Chl}$ $a$ concentrations based on the calibration with measured Chl $a$ (model 1, see Table $2 \mathrm{a}, \mathrm{b}$ for the models) or measured $\mathrm{Chl}$ $a$ and water colour estimate (model 2), absorbancebased water colour $\left(\mathrm{A}_{420}\right.$, model 3) or in situ OM fluorescence (model 4). Solid line = 1:1 line; $M A E$ mean absolute percentage error (\%), $M E$ modelling efficiency $(\%)$
Model 1

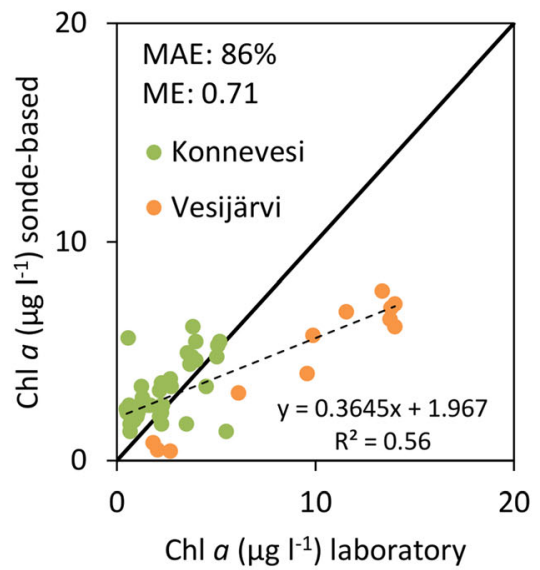

Model 3

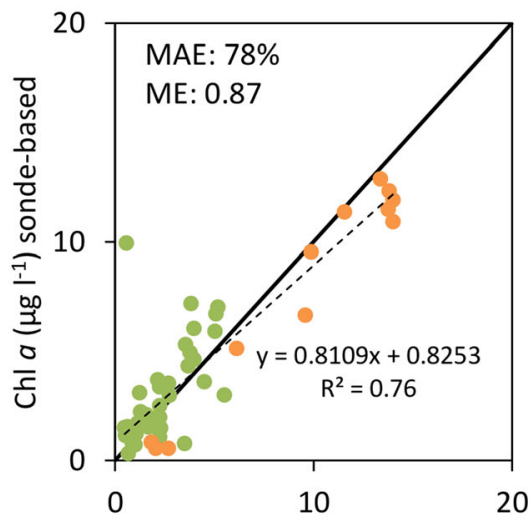

Chl $a\left(\mu \mathrm{g} \mathrm{I}^{-1}\right)$ laboratory
Model 2

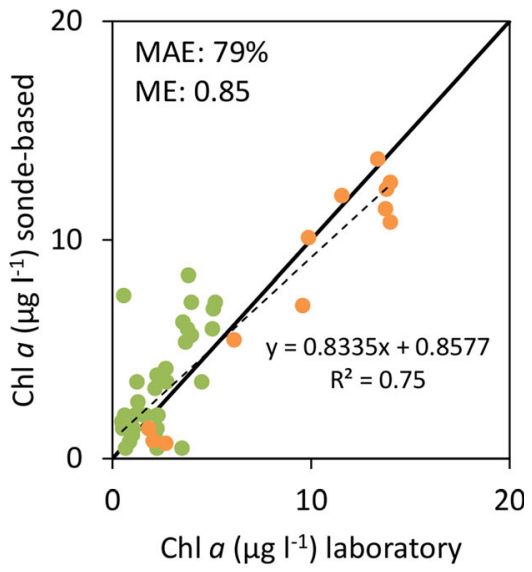

Model 4

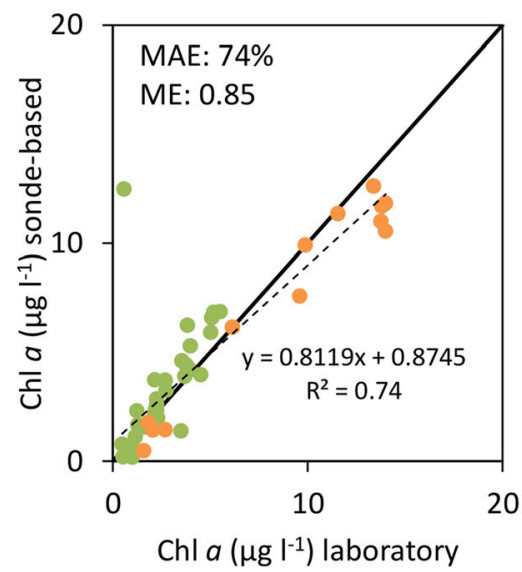

degradation and lower import of CDOM (e.g. Müller et al., 2014). Deploying, for example, an on-line UV Vis spectrophotometer in conjunction with the continuous Chl measurements could reveal more details in the changes of OM quality during the growing season.

As demonstrated by the scrutinization of two humic and two clear water lakes, predictability between Chl $a$ analysed in laboratory and measured in situ varied slightly between lakes after OM calibrations. In the clearwater lakes, predictability stayed lower than in humic lakes, likely due to interfering factors other than organic matter. It has been shown that in one of the clear water lakes, Lake Vesijärvi, Chl fluorescence is influenced by the high amount of cyanobacteria, and therefore the calibration of the Chl fluorometer with microscopic counts of cyanobacteria biomass was found effective for increasing the accuracy of $\mathrm{Chl}$ fluorometer results (compared to Chl $a$ alone extracted in the laboratory, (Anttila et al., 2012). In this study, we did not study algal pigment abundance or algal community composition. Chl fluorescence might vary between day and night as well, being higher at night when photosynthetic activity is lower (Aiken, 1981). In clear water lakes, phytoplankton may have to protect their photosystems from photobleaching through non-photochemical quenching processes (Suggett et al., 2010). The consequence of this is a suppression of fluorescence, which should be corrected in cases of high irradiance. In Finnish lakes, this situation is typically limited to very shallow depths at the surface and to a greater extent, to only few lakes and few days of summer. Watras et al. (2011) demonstrated temperature quenching of $\mathrm{Chl}$ readings that could be overcome by temperature calibration of the fluorometer data. As we did our measurements in rather uniform summer temperatures, temperature quenching is likely a minor source of variation in our data. 


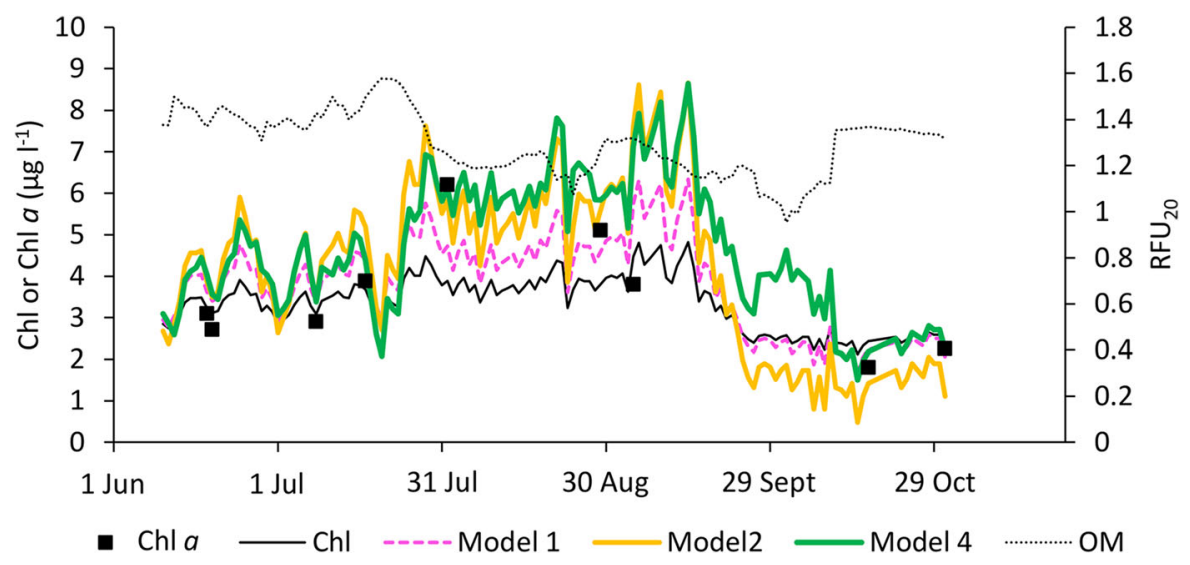

Fig. 7 On-line in situ Chl $\left(\mu \mathrm{g} \mathrm{l}^{-1}\right)$ and OM fluorescence $\left(\mathrm{RFU}_{20}\right)$ in Lake Konnevesi in 2013. Chl was yielded by the fluorometer (Sonde 1) and models 1-2 and 4 are described in Table 2. Chl $a$ refers to laboratory analysis of Chl $a$ from samples

\section{Conclusions}

Comparison of Chl fluorescence is generally incorrect in water bodies with different humic contents if the calibration procedures for $\mathrm{OM}$ are not conducted. OM fluorescence causes errors in estimation of Chl that are not consistent between lakes or even within lakes. Our calibration procedures, including water colour, laboratory assessments or in situ OM fluorescence, were each demonstrated to be promising and practical methods for the in situ Chl fluorometer data calibration for boreal humic waters. Our rather limited results from the continuously monitored Lake Konnevesi suggest that changes in OM quantity in a single water body may not affect the calibration in great extent, but this requires further scrutinization.

Acknowledgements Open access funding provided by University of Jyväskylä (JYU). The work of Jonna Kuha was financially supported by VALUE Doctoral Program in Integrated Catchment and Water Resources Management, funded by the Academy of Finland. This work also received financial support from the Finnish Academy projects Terla (No. 263472) and MiDAS (No. 311229) for Marko Järvinen. Finnish Cultural Foundation supported the work of Pauliina Salmi.

Open Access This article is distributed under the terms of the Creative Commons Attribution 4.0 International License (http:// creativecommons.org/licenses/by/4.0/), which permits unrestricted use, distribution, and reproduction in any medium, provided you give appropriate credit to the original author(s) and the source, provide a link to the Creative Commons license, and indicate if changes were made.

Data availability The datasets generated and analysed during this study are available in the University of Jyväskylä JYX repository with https://doi.org/10.17011/jyx/dataset/62634 and URI: http://urn.fi/URN:NBN:fi:jyu-201901291351

\section{References}

Aiken, J., 1981. A chlorophyll sensor for automatic remote operation in the marine-environment. Marine Ecology Progress Series 4: 235-239.

Anttila, S., M. Ketola, K. Vakkilainen \& T. Kairesalo, 2012. Assessing temporal representativeness of water quality monitoring data. Journal of Environmental Monitoring 14: 589-595.

Carder, K. L., S. Hawes, K. Baker, R. Smith, R. Steward \& B. Mitchell, 1991. Reflectance model for quantifying chlorophyll a in the presence of productivity degradation products. Journal of Geophysical Research: Oceans 96: 20599-20611.

Carlson, R. E. \& J. Shapiro, 1981. Dissolved humic substances: a major source of error in fluorometric analyses involving lake waters1. Limnology and Oceanography 26: 785-790.

Coble, P. G., J. Lead, A. Baker, D. M. Reynolds \& R. G. Spencer, 2014. Aquatic Organic Matter Fluorescence. Cambridge University Press, Cambridge.

Cremella, B., Y. Huot \& S. Bonilla, 2018. Interpretation of total phytoplankton and cyanobacteria fluorescence from cross calibrated fluorometers, including sensitivity to turbidity and colored dissolved organic matter. Limnology and Oceanography: Methods 16: 881-894.

Dolman, A. M. et al., 2015. Final report for the project CEN M424 WP6. Development and inter-laboratory comparison to enhance the draft European Standard on water qualityguidance on quantitative and qualitative sampling of phytoplankton from inland waters based on draft document N118 (2008/04/15).

Downing, B. D., B. A. Pellerin, B. A. Bergamaschi, J. F. Saraceno \& T. E. Kraus, 2012. Seeing the light: the effects of particles, dissolved materials, and temperature on in situ measurements of DOM fluorescence in rivers and streams. Limnology and Oceanography: Methods 10: 767-775. 
Evans, C. D., T. G. Jones, A. Burden, N. Ostle, P. Zieliński, M. D. Cooper, M. Peacock, J. M. Clark, F. Oulehle \& D. Cooper, 2012. Acidity controls on dissolved organic carbon mobility in organic soils. Global Change Biology 18: 3317-3331.

Goldman, E. A., E. M. Smith \& T. L. Richardson, 2013. Estimation of chromophoric dissolved organic matter (CDOM) and photosynthetic activity of estuarine phytoplankton using a multiple-fixed-wavelength spectral fluorometer. Water research 47: 1616-1630.

Hessen, D. O. \& L. J. Tranvik, 1998. Humic substances as ecosystem modifiers-introduction. Aquatic Humic Substances. Springer, Berlin, Heidelberg: 1-6.

Jennings, E., S. Jones, L. Arvola, P. A. Staehr, E. Gaiser, I. D. Jones, K. C. Weathers, G. A. Weyhenmeyer, C. CHIU \& E. De Eyto, 2012. Effects of weather related episodic events in lakes: an analysis based on high frequency data. Freshwater Biology 57: 589-601.

Keskitalo, J. \& P. Eloranta (eds), 1999. Limnology of Humic Waters. Backhuys, Leiden.

Klug, J. L., D. C. Richardson, H. A. Ewing, B. R. Hargreaves, N. R. Samal, D. Vachon, D. C. Pierson, A. M. Lindsey, D. M. O’Donnell \& S. W. Effler, 2012. Ecosystem effects of a tropical cyclone on a network of lakes in northeastern North America. Environmental Science \& Technology 46: 11693-11701.

Kritzberg, E. \& S. Ekström, 2012. Increasing iron concentrations in surface waters - a factor behind brownification? Biogeosciences 9: 1465-1478.

Lavigne, H., F. D’ortenzio, H. Claustre \& A. Poteau, 2012. Towards a merged satellite and in situ fluorescence ocean chlorophyll product. Biogeosciences 9: 2111-2125.

Leppä, M., J. Karjalainen \& A. Holopainen, 1995. In vivo-fluorescence and chlorophyll a determination in Finnish humic lakes. Aqua Fennica 25: 33-38.

Lorenzen, C. J., 1967. Determination of chlorophyll and phaeopigments: spectrophotometric equations 1. Limnology and Oceanography 12: 343-346.

Matilainen, A., E. T. Gjessing, T. Lahtinen, L. Hed, A. Bhatnagar \& M. Sillanpää, 2011. An overview of the methods used in the characterisation of natural organic matter (NOM) in relation to drinking water treatment. Chemosphere 83: 1431-1442.

Mayer, D. \& D. Butler, 1993. Statistical validation. Ecological Modelling 68: 21-32.

Meinson, P., A. Idrizaj, P. Nõges, T. Nõges \& A. Laas, 2015. Continuous and high-frequency measurements in limnology: history, applications, and future challenges. Environmental Reviews 24: 52-62.

Monteith, D. T., J. L. Stoddard, C. D. Evans, H. A. De Wit, M. Forsius, T. Høgåsen, A. Wilander, B. L. Skjelkvåle, D. S. Jeffries \& J. Vuorenmaa, 2007. Dissolved organic carbon trends resulting from changes in atmospheric deposition chemistry. Nature 450: 537.

Müller, R. A., D. N. Kothawala, E. Podgrajsek, E. Sahlée, B. Köhler, L. J. Tranvik \& G. A. Weyhenmeyer, 2014. Hourly, daily, and seasonal variability in the absorption spectra of chromophoric dissolved organic matter in a eutrophic, humic lake. Journal of Geophysical Research: Biogeosciences 119: 1985-1998.
Ostrowska, M., 2012. Model of the dependence of the sun-induced chlorophyll a fluorescence quantum yield on the environmental factors in the sea. Optics Express 20: 23300-23317.

Proctor, C. W. \& C. S. Roesler, 2010. New insights on obtaining phytoplankton concentration and composition from in situ multispectral chlorophyll fluorescence. Limnology and Oceanography: Methods 8: 695-708.

Richardson, T. L., E. Lawrenz, J. L. Pinckney, R. C. Guajardo, E. A. Walker, H. W. Paerl \& H. L. MacIntyre, 2010. Spectral fluorometric characterization of phytoplankton community composition using the Algae Online Analyser®. Water research 44: 2461-2472.

Seppälä, J. \& M. Balode, 1998. The use of spectral fluorescence methods to detect changes in the phytoplankton community. Eutrophication in Planktonic Ecosystems: Food Web Dynamics and Elemental Cycling. Springer, Dordrecht: 207-217.

Serra, T., C. Borrego, X. Quintana, L. Calderer, R. López \& J. Colomer, 2009. Quantification of the effect of nonphotochemical quenching on the determination of in vivo chl a from phytoplankton along the water column of a freshwater reservoir. Photochemistry and Photobiology 85: 321-331.

SFS-EN-ISO 7887, 2011. Water quality-Examination and determination of colour. International Organization for Standardization, Geneva, Switzerland

SFS-ISO 10260, 1992. Water quality-measurement of biochemical parameters-spectrometric determination of the chlorophyll - a concentration. International Organization for Standardization, Geneva, Switzerland

Strickland, J. D., 1968. Continuous measurement of in vivo chlorophyll; a precautionary note. Deep Sea Research and Oceanographic Abstracts 15: 225-227.

Suggett, D. J., O. Prášil \& M. A. Borowitzka, 2010. Chlorophyll a fluorescence in aquatic sciences: methods and applications. Springer, Dordrecht.

Twiss, M. R., 2011. Variations in chromophoric dissolved organic matter and its influence on the use of pigmentspecific fluorimeters in the Great Lakes. Journal of Great Lakes Research 37: 124-131.

Watras, C., P. Hanson, T. Stacy, K. Morrison, J. Mather, Y. Hu \& P. Milewski, 2011. A temperature compensation method for CDOM fluorescence sensors in freshwater. Limnology and Oceanography: Methods 9: 296-301.

Williams, R. T. \& J. W. Bridges, 1964. Fluorescence of solutions: a review. Journal of clinical pathology 17: 371-394.

Xing, X., H. Claustre, E. Boss, C. Roesler, E. Organelli, A. Poteau, M. Barbieux \& F. D’Ortenzio, 2017. Correction of profiles of in situ chlorophyll fluorometry for the contribution of fluorescence originating from non-algal matter. Limnology and Oceanography: Methods 15: 80-93.

Zeng, L. \& D. Li, 2015. Development of in situ sensors for chlorophyll concentration measurement. Journal of Sensors. https://doi.org/10.1155/2015/903509.

Publisher's Note Springer Nature remains neutral with regard to jurisdictional claims in published maps and institutional affiliations. 